\title{
Elimination of polar micropollutants and anthropogenic markers by wastewater treatment in Beijing, China
}

\author{
Weixiao Qi ${ }^{\mathrm{a}}$, Heinz Singer ${ }^{\mathrm{b}}$, Michael Berg ${ }^{\mathrm{b}, *}$, Beat Müller $^{\mathrm{c}}$, Benoit Pernet-Coudrier ${ }^{\mathrm{b}}$, Huijuan Liu ${ }^{\mathrm{a}, *}$, \\ Jiuhui $\mathrm{Qu}^{\mathrm{a}}$
}

${ }^{a}$ Key Laboratory of Drinking Water Science and Technology, Research Center for Eco-Environmental Sciences, Chinese Academy of Sciences, Beijing 100085, China

${ }^{\mathrm{b}}$ Eawag, Swiss Federal Institute of Aquatic Science and Technology, 8600 Dübendorf, Switzerland

${ }^{\mathrm{c}}$ Eawag, Swiss Federal Institute of Aquatic Science and Technology, 6047 Kastanienbaum, Switzerland

\section{H I G H L I G H T S}

- The studied wastewater facilities are representative for large cities in China.

- The occurrence, elimination efficiency, and per-capita loads were assessed.

- Pollutant patterns were similar as in Europe, including caffeine and sucralose.

- Total per capita pollutant loads are currently lower than in Western countries.

- Wastewater used directly for irrigation poses a threat to soils and food safety.

\section{A R T I C L E I N F O}

\section{Article history:}

Received 30 May 2014

Received in revised form 26 August 2014

Accepted 7 September 2014

Available online 8 October 2014

Handling Editor: Klaus Kümmerer

\section{Keywords}

Wastewater

Irrigation

Pharmaceutical

Personal care product

Household chemical

Pesticide

\begin{abstract}
A B S T R A C T
Anthropogenic contamination of surface waters in Asia is on the increase. While polar organic contaminants are gradually recognized for their impacts on aquatic ecosystems in the Western World, less is known about the situation in Asia. In developing countries like China, water resources are particularly vulnerable. We investigated the occurrence, elimination, and per capita loads of a wide range of pharmaceuticals, household chemicals and pesticides in five Beijing WWTPs representative for megacities in China, and compare the efficiency of different treatment processes. Based on initial screening for 268 micropollutants using high-resolution mass spectrometry, 33 compounds were examined in detail. Pollutant concentrations in raw wastewater ranged from $<0.02 \mu \mathrm{g} \mathrm{L}^{-1}$ for pesticides to $>20 \mu \mathrm{g} \mathrm{L}^{-1}$ for caffeine and the contrast agent iopromide. Concentrations in the WWTP effluents were generally $<1 \mu \mathrm{g} \mathrm{L} \mathrm{L}^{-1}$, except for some pharmaceuticals, iopromide (1.2-18 $\left.\mu \mathrm{g} \mathrm{L} \mathrm{L}^{-1}\right)$, caffeine $\left(0.025-2.3 \mu \mathrm{g} \mathrm{L}^{-1}\right)$, and the artificial sweetener sucralose $\left(2.7-3.5 \mu \mathrm{g} \mathrm{L}^{-1}\right)$. Elimination efficiencies varied greatly from $<1 \%$ to close to $100 \%$, with macrolides, some sulfonamides, metronidazole, iopromide, and 4-acetamidoantipyrine being the most persistent compounds. Total per capita loads of the investigated micropollutants were lower than in communal wastewater of Europe, amounting to 7.9-12.2 and 2.0-6.5 $\mathrm{g} \mathrm{d}^{-1} 1000$ inhabitants ${ }^{-1}$ in the influents and effluents, respectively, with an average release of $\sim 100 \mathrm{~kg} \mathrm{~d}^{-1}$ by the 11.4 million people and 2.3 million $\mathrm{m}^{3}$ of wastewater treated per day. Since the wastewater effluents are often used for agricultural irrigation, residual organic pollutants pose a threat to food safety, the development of antibacterial resistance, and combined effects of micropollutants in the aquatic environment.
\end{abstract}

(c) 2014 Elsevier Ltd. All rights reserved.

\section{Introduction}

Increasing contamination of aquatic systems by polar organic micropollutants is a major problem for aquatic life worldwide.

\footnotetext{
* Corresponding authors. Tel.: +41 587655078 (M. Berg), +86 1062849128 (H. Liu).

E-mail addresses: michael.berg@eawag.ch (M. Berg), hjliu@rcees.ac.cn (H. Liu).
}

These chemicals, which can include pharmaceuticals as well as personal care products (PPCPs), household chemicals, and pesticides, are often not efficiently eliminated by conventional wastewater treatment and are therefore discharged continuously to surface waters. Verlicchi et al. (2012) reviewed the elimination of pharmaceutical compounds after secondary treatment in WWTPs worldwide and discussed factors that influenced elimination efficiency. Parameters of the treatment processes such as sludge 
retention time (SRT), hydrological retention time (HRT), $\mathrm{pH}$, temperature, and physico-chemical properties of the compounds were important factors that determined removal from wastewater. Generally, an increased SRT, an HRT longer than the half-life time of the compounds, and high temperature help to biodegrade pharmaceuticals during the treatment process. However, compounds such as sulfamethoxazole, carbamazepine, and sucralose show generally low or fluctuating elimination efficiencies, even with high SRT and HRT. Miège et al. (2009) assessed the elimination efficiency of PPCPs in WWTPs by compiling 6641 data for 184 PPCPs, and pointed out a low elimination efficiency $(<30 \%)$ for atenolol, carbamazepine, metoprolol, trimethoprim, mefenamic acid, and clofibric acid.

The Haihe River Basin is located in the water-scarce area of the North China Plain and is home to several megacities, including Beijing and Tianjin. This area is facing a crisis for water resources due to rapid development and 25 years of drought $\left(<600 \mathrm{~mm} \mathrm{yr}^{-1}\right.$, average $450 \mathrm{~mm} \mathrm{yr}^{-1}$ ) recorded since the 1970s. Consequently, wastewater (WW), both treated and untreated, is the main water source of many rivers in the area. Recently, the occurrence, transport, and bioaccumulation of antibiotics, including tetracycline, sulfonamide, quinolone, and macrolide families, were studied in the Haihe River (Luo et al., 2011; Gao et al., 2012a). Sulfonamides, which have high solubility and chemical stability in water, occurred at the highest concentrations (24-385 $\mathrm{ng} \mathrm{L}^{-1}$ ) and detection frequencies (76-100\%) (Luo et al., 2011). Ciprofloxacin and erythromycin were found to bio-accumulate in crucian carp in the Haihe River (Gao et al., 2012a). Pharmaceuticals and most household chemicals in rivers downstream of Beijing originate from urban wastewaters, especially from WWTP effluent discharges, as most compounds are poorly eliminated by the conventional treatment processes applied in Beijing's major WWTPs (Heeb et al., 2012).

Several studies have focused on the occurrence and elimination efficiency of pharmaceuticals, caffeine, and DEET in the WWTPs of Beijing (Sui et al., 2010, 2011; Zhou et al., 2010; Li et al., 2013). The pharmaceuticals included antibiotics, lipid regulators, beta-blockers, and antiphlogistics and varied in concentration from several $n \mathrm{~L} \mathrm{~L}^{-1}$ to thousands of $\mathrm{ng} \mathrm{L}^{-1}$ in the influents and from below detection to hundreds of $\mathrm{ng} \mathrm{L}^{-1}$ in the effluents. The elimination efficiency also varied widely from no or low elimination of carbamazepine to $86 \%$ elimination of difloxacin. A membrane bioreactor (MBR) and an oxidation ditch, both with a high HRT ( $>12 \mathrm{~h}$ ), were more efficient than a conventional activated sludge process at removing easily biodegradable compounds. According to Ort et al. (2010a,b), uncertainties in the concentrations were probably due to the use of grab sampling for sampling of the inflow.

In 2009, Heeb et al. (2012) studied the rivers downstream of Beijing and screened for 268 organic pollutants including pharmaceuticals, pesticides, biocides, household chemicals, and associated metabolites. Following this initial screening, these authors conducted a comprehensive assessment over a time span of 14 months, focusing on the seasonal occurrence of 62 polar compounds, including pharmaceuticals, pesticides and associated metabolites, and household chemicals. This long-term investigation revealed that pharmaceuticals and the majority of household chemicals in the rivers originated from urban wastewater discharge (Heeb et al., 2012). The present study was conducted to document the occurrence and elimination of these same polar organic micropollutants in five Beijing WWTPs that apply different treatment processes, including conventional activated sludge, oxidation ditches, and MBR. The influence of HRT, SRT, and type of treatment process on the pollutant elimination efficiencies in these WWTPs is discussed, with the aim of extending knowledge on the occurrence and elimination of pharmaceuticals and household chemicals in Beijing's WWTPs.

\section{Materials and methods}

\subsection{Characteristics of Beijing's WWTPS}

This study investigated the five WWTPs with the highest treatment capacities in Beijing (Gaobeidian, Xiaohongmen, Qinghe, Jiuxianqiao, and Beixiaohe) (Fig. 1). These WWTPs treat a total of about 2.28 million $\mathrm{m}^{3}$ of wastewater per day and are responsible for $90 \%$ of Beijing's wastewater discharge into the Haihe River system. The WWTP characteristics are summarized in Table 1.

\subsection{Sample collection and analysis}

Time-proportional 24-h composite samples of the influents and effluents were collected from the WWTPs in March 2011. This sampling procedure presents a snapshot in time and does not account for short-term fluctuations occurring during the course of $1 \mathrm{~d}$. It also does not capture monthly or seasonal variations. Elimination rates derived in our study for March 2011 can therefore be seen as approximate values, but may underestimate pesticide loads as March is at the early stage of the application period. Wastewater samples $(250 \mathrm{~mL})$ were collected in baked-glass bottles (Schott), packed in cooled containers, and shipped within $\leqslant 7 \mathrm{~d}$ to Eawag in Switzerland, where the samples were frozen at $-20^{\circ} \mathrm{C}$ until analysis. Immediately prior to analysis, the thawed samples were filtered through glass fiber filters (GF/F, pore size $0.7 \mu \mathrm{m}$, Whatman) and an isotope-labeled internal standard (IS) solution was added. Following an initial screening for 268 micropollutants using high-resolution mass spectrometry, a total of 18 pharmaceuticals, 9 pesticides and associated metabolites, and 6 household chemicals were selected for detailed investigation and analyzed using a fully automated solid phase extraction (SPE) system (Stoob et al., 2005) coupled directly to a liquid chromatography (LC) tandem mass spectrometer. The analytical method has been described in our previous study (Heeb et al., 2012). Briefly, for targets where no structurally identical internal standard (IS) was available, the IS with the most similar retention time was used

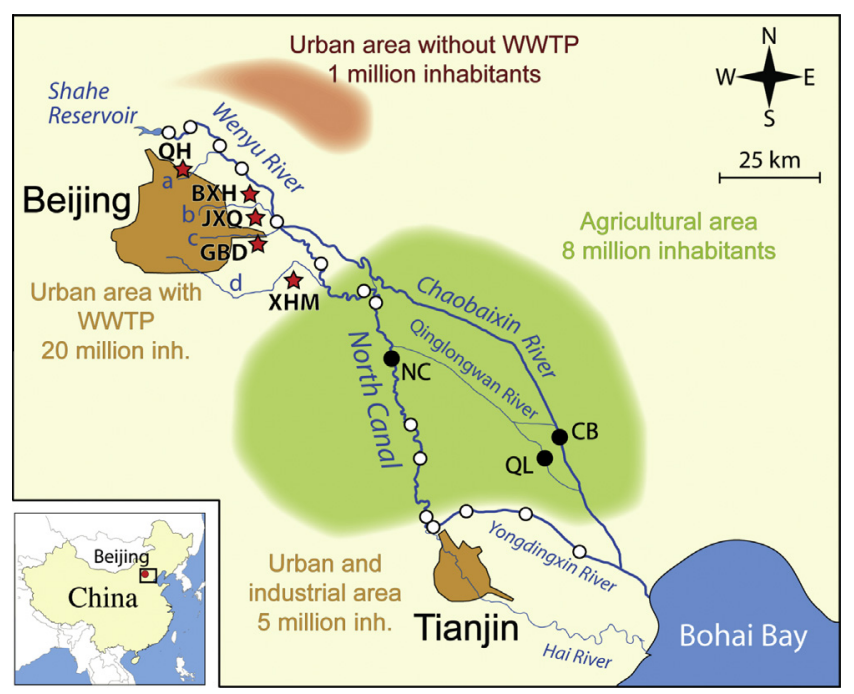

Fig. 1. Map of the Beijing region depicting the land use and population. The red stars indicate the locations of the investigated WWTPs, which specifically are the WWTPs of Qinghe (QH), Beixiaohe (BXH), Jiuxianqiao (JXQ), Gaobeidian (GBD), and Xiaohongmen (XHM). Open circles and black dots represent sites along the wastewater-receiving rivers investigated in our earlier study (Heeb et al., 2012). Letters a-d denote urban rivers draining the wastewater effluents of Beijing, which are (a) Qing River; (b) Beixiao River, (c) Tonghui River, and (d) Liangshui River. (For interpretation of the references to color in this figure legend, the reader is referred to the web version of this article.) 
Table 1

Characteristics of the five major WWTPs of Beijing and Pharmaceuticals with high or moderate elimination rates in these WWTPs.

\begin{tabular}{|c|c|c|c|c|c|c|}
\hline WWTP & $\begin{array}{l}\text { Inhabitants } \\
\text { served (Mio) }\end{array}$ & $\begin{array}{l}\text { Capacity } \\
\left(\text { Mio } \mathrm{m}^{3} \mathrm{~d}^{-1}\right)\end{array}$ & $\begin{array}{l}\text { Main treatment } \\
\text { process }\end{array}$ & $\begin{array}{l}\text { HRT } \\
(\mathrm{h})\end{array}$ & $\begin{array}{l}\text { SRT } \\
\text { (d) }\end{array}$ & Substances with high or moderate elimination rates in this study (\%) \\
\hline $\begin{array}{l}\text { Jiuxianqiao } \\
\text { (JXQ) }\end{array}$ & 1.0 & 0.2 & Oxidation Ditch & 15 & 13 & $\begin{array}{l}\text { Sulfamethoxazole + N4-acetylsulfamethoxazole ( } 82 \%) \text {, atenolol acid (79\%), } \\
\text { sulfadiazine ( } 74 \%) \text {, sulfapyridine (71\%), iopromide ( } 71 \%)\end{array}$ \\
\hline Qinghe $(\mathrm{QH})$ & 2.0 & 0.4 & $\mathrm{~A} / \mathrm{A} / \mathrm{O}$ & 11 & 13 & $\begin{array}{l}\text { Sulfamethoxazole + N4-acetylsulfamethoxazole (81\%), sulfadiazine ( } 72 \%) \text {, } \\
\text { sulfapyridine (60\%), iopromide (52\%) }\end{array}$ \\
\hline $\begin{array}{l}\text { Gaobeidian } \\
\text { (GBD) }\end{array}$ & 4.9 & 1.0 & $\mathrm{~A} / \mathrm{A} / \mathrm{O}$ & 11 & 20 & Iopromide (90\%), sulfamethoxazole + N4-acetylsulfamethoxazole (66\%) \\
\hline $\begin{array}{l}\text { Beixiaohe } \\
\text { (BXH) }\end{array}$ & 0.5 & 0.1 & MBR & 17 & 20 & $\begin{array}{l}\text { Sulfamethoxazole + N4-acetylsulfamethoxazole (66\%), sulfadiazine (54\%), } \\
\text { sulfapyridine (52\%) }\end{array}$ \\
\hline $\begin{array}{l}\text { Xiaohongmen } \\
\quad(\mathrm{XHM})\end{array}$ & 3.0 & 0.6 & $\mathrm{~A} / \mathrm{A} / \mathrm{O}$ & 11 & 15 & $\begin{array}{l}\text { Sulfadiazine ( } 60 \%) \text {, sulfapyridine ( } 55 \%) \text {, sulfamethoxazole + N4- } \\
\text { acetylsulfamethoxazole ( } 52 \%)\end{array}$ \\
\hline
\end{tabular}

HRT: Hydraulic retention time; SRT: Sludge retention time; A/A/O: Anaerobic/anoxic/aerobic; MBR: Membrane bioreactor.

for quantification. The average relative recoveries were between $85-112 \%$ for all compounds except for imidacloprid (77\%) and clindamycin (132\%).

\section{Results and discussion}

\subsection{Occurrence and elimination of household chemicals in WWTPS}

\subsubsection{Caffeine}

Caffeine being one of the most abundant household chemicals present in tea, coffee, or analgesics, has the highest concentrations in the influents of the WWTPs (22.1-25.9 $\mu \mathrm{g} \mathrm{L}^{-1}$, Table 2) among the six household substances detected in this study. Due to its low persistence during biological treatment process (half lives $\sim 0.8-5 \mathrm{~h}$, Buerge et al., 2006) caffeine was largely eliminated (>90\%, Fig. 2) by all WWTPs, leaving residual concentrations of $25-2340 \mathrm{ng} \mathrm{L}^{-1}$ in the effluents. This behavior was in agreement with those of other studies (Buerge et al., 2003, 2006; Sui et al., 2010). The elimination efficiency for caffeine by WWTPs has been reported to be related to sludge age (Buerge et al., 2003). The sludge residence time of $13-20 \mathrm{~d}$ in the Beijing WWTPs (Table 1) was therefore consistent with the high elimination efficiency for caffeine, which had effluent concentrations ranging from 25 to $350 \mathrm{ng} \mathrm{L}^{-1}$ if one sample from the XHM WWTP was excluded (Table 2, Fig. S1). Therefore, caffeine can be used as an anthropogenic marker for the efficiency of WWTPs (Standley et al., 2000; Buerge et al., 2003).

\subsubsection{Sucralose}

Sucralose, which has been used in many studies as an indicator of domestic wastewater loads to surface waters, ranged in concentration from 3.21 to $5.04 \mu \mathrm{g} \mathrm{L}^{-1}$ in the inflow and from 2.76 to $3.50 \mu \mathrm{g} \mathrm{L}^{-1}$ in the outflow (Table 2). The effluent concentrations of sucralose were within the lower range of the world levels, reported at $0.4-11.0 \mu \mathrm{g} \mathrm{L}^{-1}$ (Tollefsen et al., 2012), but were significantly lower than those of most WWTPs in the USA where sucralose concentrations in effluents reached as high as $119 \mu \mathrm{g} \mathrm{L}^{-1}$ (Mead et al., 2009). Although the sucralose concentration determined in our study was lower than that in most WWTPs in the USA and Europe, the low elimination efficiency (6-31\%, Fig. 2) was similar in Beijing.

Sucralose is very stable during WW treatment as well as in surface waters, making it a good indicator for wastewater in surface waters. The average sucralose concentrations in WWTP effluents and the actual concentrations in the river can be used to estimate the fraction of wastewater discharged to the river, assuming that seasonal variations of sucralose loads are small due to its steady household use throughout the year. Sucralose concentrations in the rivers of Beijing were reported in our earlier study (Heeb et al., 2012) as $1360 \mathrm{ng} \mathrm{L}^{-1}, 1270 \mathrm{ng} \mathrm{L}^{-1}$, and $1040 \mathrm{ng} \mathrm{L}^{-1}$ at the sites NC, CB, and QL (Fig. 1), with water discharge estimates of $18.5 \mathrm{~m}^{3} \mathrm{~s}^{-1}, 7.5 \mathrm{~m}^{3} \mathrm{~s}^{-1}$, and $5.9 \mathrm{~m}^{3} \mathrm{~s}^{-1}$. We used the average concentration of the three river sections $\left(1.22 \mu \mathrm{g} \mathrm{L}^{-1}\right)$ and the concentration determined in WWTP effluents (3.06 $\mu \mathrm{g} \mathrm{L}^{-1}$; Table 2) to estimate that the river water consisted of $44 \%$ wastewater, corre-

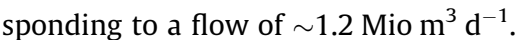

The estimated WW discharge from all five TPs was $\sim 2.3$ Mio $\mathrm{m}^{3} \mathrm{~d}^{-1}$ (Table 1); hence, we find that about half of the WW was not discharged to the river but used as reclaimed water for special purposes. At the GBD WWTP, for example, about one half of the secondary effluents are used as industrial cooling water, landscaping water, and irrigation water in urban green lands, and $10000 \mathrm{~m}^{3} \mathrm{~d}^{-1}$ are used on the WWTP premises for filter cleaning, truck washing, and gardening.

\subsubsection{Benzotriazole}

The corrosion inhibitors benzotriazole and 4-/5-methyl-benzotriazole occurred in the WWTP influents at concentrations of 550$1380 \mathrm{ng} \mathrm{L}^{-1}$ and 310-630 $\mathrm{ng} \mathrm{L}^{-1}$, respectively. These levels were much lower than those reported for WWTPs in Berlin (Germany) with samples collected between June and December of 2006, where concentrations were $17-44 \mu \mathrm{g} \mathrm{L}^{-1}$ for benzotriazole and $1.1-4.9 \mu \mathrm{g} \mathrm{L}^{-1}$ for the sum of 4-methyl-benzotriazole and 5-methyl-benzotriazole (Reemtsmaa et al., 2010). The sampling time (March) in this study was probably one of the reasons for the low concentration of these corrosion inhibitors included in aircraft de-icing fluid and motor vehicle antifreeze. In Beijing, benzotriazole was moderately eliminated (56-74\%), whereas 4-/5-methyl-benzotriazole elimination was limited (2-37\%) (Fig. 2). These elimination efficiencies are comparable to those observed for WWTPs in Berlin (Germany), which were 30-55\% for benzotriazole, $20-70 \%$ for 5-methyl-benzotriazole and insignificant for 4-methyl-benzotriazole (Reemtsmaa et al., 2010).

\subsection{Occurrence and elimination of pharmaceuticals by WWTPS}

\subsubsection{Antibiotics}

The inflows and outflows of the WWTPs included 10 antibiotics and one antifungal: sulfadiazine (SFDZ), sulfapyridine (SFPD), sulfamethoxazole (SMX) and its metabolite N4-Acetylsulfamethoxazole $\left(\mathrm{N}_{4}\right.$-AcSMX), erythromycin (and $-\mathrm{H}_{2} \mathrm{O}$ ) (ERT), clarithromycin (CTM), metronidazole (MTNZ), trimethoprim (TMTP), sulfamethazine (SFMT) and fluconazole (FCNZ), which ranged in concentrations from 110 to $640 \mathrm{ng} \mathrm{L}^{-1}$ in the influents and from 40 to $900 \mathrm{ng} \mathrm{L}^{-1}$ in the effluents (except for sulfamethazine, which was always below $20 \mathrm{ng} \mathrm{L}^{-1}$ ). These concentrations were similar to the values reported in an international database compiled from 117 publications of PPCPs in wastewater treatment plants around the globe (Miège et al., 2009); for example, erythromycin (and $\mathrm{H}_{2} \mathrm{O}$ ) was present at $270-290 \mathrm{ng} \mathrm{L}^{-1}$ in the effluents of Beijing vs. 
Table 2

Concentrations and eliminations of pharmaceuticals, household chemicals, and pesticides in influents and effluents of WWTPs in Beijing.

\begin{tabular}{|c|c|c|c|c|c|c|c|}
\hline \multirow[t]{2}{*}{ Substances } & & & \multirow{2}{*}{$\begin{array}{l}\mathrm{LOQ}^{\mathrm{a}} \\
\left(\mathrm{ng} \mathrm{L}^{-1}\right)\end{array}$} & \multirow{2}{*}{$\begin{array}{l}\text { Recovery } \\
(\%)\end{array}$} & \multicolumn{2}{|c|}{ Concentration (ng L ${ }^{-1}$ ) } & \multirow{2}{*}{$\begin{array}{l}\text { Elimination }{ }^{\mathrm{f}} \\
(\%)\end{array}$} \\
\hline & & & & & $\begin{array}{l}\text { Influent } \\
(\mathrm{n}=5)\end{array}$ & $\begin{array}{l}\text { Effluent } \\
(\mathrm{n}=5)\end{array}$ & \\
\hline \multicolumn{8}{|l|}{ Pharmaceuticals } \\
\hline \multirow[t]{10}{*}{ Antibiotics } & Sulfonamides & Sulfamethoxazole & 33 & 94 & $300-460$ & $100-250$ & $33-72$ \\
\hline & & N4-Acetylsulfamethoxazole & 2 & 90 & $460-640$ & $40-320$ & $50-92$ \\
\hline & & $\mathrm{SMX}+\mathrm{N}_{4}-\mathrm{AcSMX}^{\mathrm{c}}$ & & & $810-1100$ & $150-530$ & $52-82$ \\
\hline & & Sulfadiazine ${ }^{*}$ & 30 & 91 & $190-320$ & $70-130$ & $44-74$ \\
\hline & & Sulfapyridine ${ }^{*}$ & 15 & 90 & $130-220$ & $50-100$ & $29-71$ \\
\hline & & Trimethoprim ${ }^{*}$ & 15 & 110 & $300-370$ & $200-370$ & $<1-35$ \\
\hline & & Sulfamethazine* & 3 & 90 & $10-20$ & $3-6$ & $63-100$ \\
\hline & Macrolides & Erythromycin (and $-\mathrm{H}_{2} \mathrm{O}$ ) & 22 & 86 & $330-390$ & $270-290$ & $19-28$ \\
\hline & & Clarithromycin ${ }^{*}$ & 14 & 89 & $130-260$ & $130-260$ & -22 to 41 \\
\hline & Nitroimidazoles & Metronidazole & 11 & 99 & $140-380$ & $250-900$ & -320 to $33^{e}$ \\
\hline Antifungal & Pyrrolic & Fluconazole $^{*}$ & 6 & 92 & $110-170$ & $110-170$ & $<10$ \\
\hline \multirow{2}{*}{$\begin{array}{l}\text { Analgesics/anti- } \\
\text { inflammatories }\end{array}$} & & 4-Acetamidoantipyrine & 31 & 72 & $1520-2520$ & $1300-2240$ & -22 to 27 \\
\hline & & Diclofenac ${ }^{*}$ & 17 & 88 & $180-280$ & $140-300$ & -7 to 25 \\
\hline \multirow[t]{2}{*}{ Antiepileptics } & & Carbamazepine* & 16 & 92 & $60-100$ & $70-110$ & -13 to 4 \\
\hline & & $\begin{array}{l}\text { Carbamazepine-10,11-dihydro-10,11- } \\
\text { dihydroxy }\end{array}$ & 2 & 93 & $650-1020$ & $450-560$ & $29-45$ \\
\hline$\beta$-Blocker & & Atenolol acid & 5 & 86 & $940-1380$ & $280-1240$ & $10-79$ \\
\hline Contrast agent & & Iopromide $^{*}$ & 18 & 101 & $2510-21300$ & $1160-17800$ & $9-91$ \\
\hline Anesthetic & & Lidocaine $^{*}$ & 89 & 92 & $137-180$ & $120-180$ & $<15$ \\
\hline Pesticides & & & & & & & d \\
\hline \multirow[t]{6}{*}{ Herbicides } & & Atrazine $^{*}$ & 29 & 87 & $10-20$ & $8-19$ & \\
\hline & & Atrazine-desethyl & 9 & 91 & $17-64$ & $14-63$ & \\
\hline & & Diuron $^{*}$ & 7 & 101 & $14-31$ & $14-25$ & \\
\hline & & Metolachlor $^{*}$ & 9 & 91 & $9-30$ & $9-19$ & \\
\hline & & Prometryn & 3 & 109 & $3-4$ & $<$ LOQ-3 & \\
\hline & & Propazin-hydroxy & 2 & 114 & $4-10$ & $2-4$ & \\
\hline Insecticides & & Imidacloprid & 15 & 71 & $45-100$ & $45-106$ & \\
\hline \multirow[t]{2}{*}{ Fungicides } & & Carbendazim $^{*}$ & 3 & 84 & $360-580$ & $370-610$ & \\
\hline & & Metalaxyl & 6 & 88 & $6-17$ & $6-14$ & \\
\hline \multicolumn{8}{|l|}{ Household chemicals } \\
\hline & & Caffeine $^{*}$ & 12 & 97 & $\begin{array}{l}22100- \\
25900\end{array}$ & $25-2340$ & $91-100$ \\
\hline & & DEET $^{*}$ & 58 & 99 & $115-270$ & $77-170$ & $19-83$ \\
\hline & & Benzotriazole $^{*}$ & 16 & 86 & $550-1380$ & $226-520$ & $56-74$ \\
\hline & & Climbazole & 6 & 94 & $610-940$ & $300-615$ & $30-51$ \\
\hline & & 4-/5-Methyl-benzotriazole & 8 & 98 & $310-630$ & $260-580$ & $2-37$ \\
\hline & & Sucralose & 113 & 100 & $3210-5040$ & $2760-3500$ & $6-31$ \\
\hline
\end{tabular}

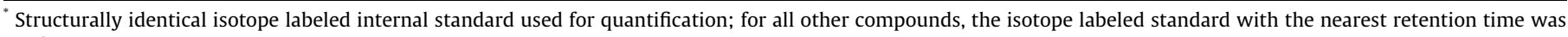
used.

Compounds in italics are transformation products.

a Limit of quantification was determined from the analyte concentration producing at least a signal-to-noise ratio of 10:1 in the sample matrix.

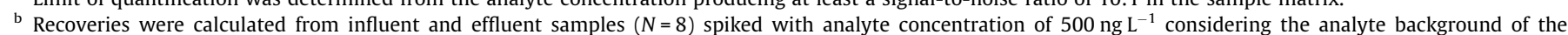
unspiked sample.

c Sum of sulfamethoxazole and N4-acetylsulfamethoxazole was calculated due to the deconjugation during the biological treatment step.

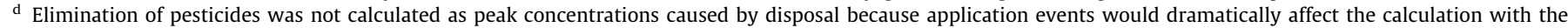
time-proportional 24-h composite sampling scheme.

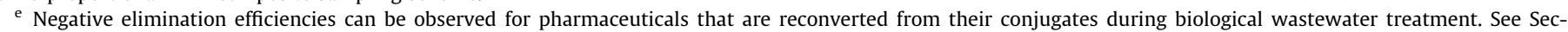
tion 3.2.1 for a more detailed discussion.

${ }^{\mathrm{f}}$ The relative uncertainty of the calculated elimination is $14 \%$ for compounds calibrated with structurally identical isotope labeled internal standards (marked by ${ }^{*}$ ), and $28 \%$ for compounds for the other compounds.

145-290 $\mathrm{ng} \mathrm{L}^{-1}$ in the database and sulfamethoxazole was present at $100-250 \mathrm{ng} \mathrm{L}^{-1}$ in Beijing vs. $18-320 \mathrm{ng} \mathrm{L}^{-1}$ in the database. Gao et al. (2012b) recently reported the occurrence and elimination efficiencies of 22 antibiotics in eight WWTPs in Beijing in May 2010, where sulfadiazine ranged between $380-2000 \mathrm{ng} \mathrm{L}^{-1}$ and $120-560 \mathrm{ng} \mathrm{L}^{-1}$ in the influents and effluents, respectively. These levels were 2-4 times higher than those found in our study although the elimination efficiencies were similar. Both studies used $24 \mathrm{~h}$ composite samples, so the differences observed for this compound could possibly be explained by seasonal variations in the raw wastewater (Sui et al., 2011; Gao et al., 2012b).

Sulfamethoxazole, its metabolite $\mathrm{N}_{4}$-acetylsulfamethoxazole, erythromycin (and $-\mathrm{H}_{2} \mathrm{O}$ ), and trimethoprim were the antibiotic compounds with the highest inflow concentrations, with average concentrations of $366,516,365$, and $318 \mathrm{ng} \mathrm{L}^{-1}$, respectively. The elimination efficiencies for sulfamethoxazole and N4-acetylsulfamethoxazole were calculated based on the sum of both compounds because deconjugation occurred during biological treatment (Kovalova et al., 2012) and was only moderate ( $>50 \%$, Table 2 ), leaving residual concentrations of $150-290 \mathrm{ng} \mathrm{L}^{-1}$ in the effluents (except for those from the XHM WWTP, at $530 \mathrm{ng} \mathrm{L}^{-1}$ ). Two other sulfonamides, sulfadiazine and sulfapyridine, were also moderately eliminated (29-74\%) (Fig. 3), with effluent concentrations being 70-130 $\mathrm{ng} \mathrm{L}^{-1}$ and $50-100 \mathrm{ng} \mathrm{L}^{-1}$, respectively (Table 2). Minimal elimination was observed for erythromycin (and $-\mathrm{H}_{2} \mathrm{O}$ ) (19-28\%) and trimethoprim (<1-35\%) by all five WWTPs (Fig. 3). 


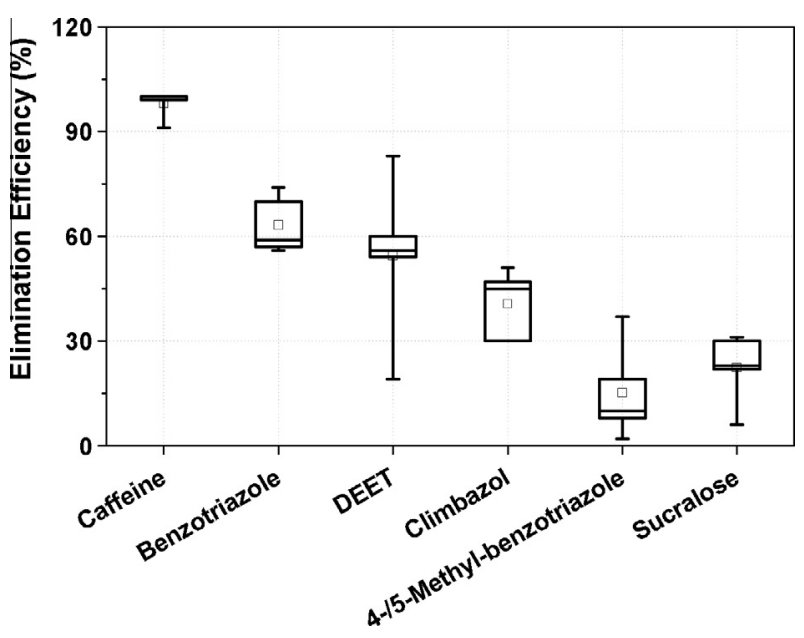

Fig. 2. Elimination efficiencies of household chemicals in WWTPs of Beijing. (DEET: N,N-Diethyl-3-methylbenzamide). Boxes illustrate the concentration ranges between the 25th and 75th percentiles. The whiskers extend to the minimum and maximum concentration values. The horizontal lines and squares inside the box indicate the median and average values, respectively.

Elimination of the antifungal drug fluconazole was negligible $(<10 \%)$, with residual concentrations of $110-170 \mathrm{ng} \mathrm{L}^{-1}$ in the effluents (Fig. 3, Table 2).

Metronidazole showed higher effluent concentrations (250$900 \mathrm{ng} \mathrm{L}^{-1}$ ) than influent concentrations (140-380 $\mathrm{ng} \mathrm{L}^{-1}$ ) in four WWTPs. A slight formation during biological treatment was also found for clarithromycin in the XHM WWTP. The same finding was reported for erythromycin (and $-\mathrm{H}_{2} \mathrm{O}$ ) and clarithromycin in WWTPs in Taiwan and South China and was explained by the presence of antibiotic conjugates (García-Glaán et al., 2008; Zhou et al., 2013) that are retransformed to the parent compounds during biological wastewater treatment.

\subsubsection{Analgesics}

Among the three analgesics/anti-inflammatory drugs detected in this study, 4-acetamidoantipyrine (AAA), a human metabolite of the analgesic metamizole, was the most abundant pharmaceutical in both influents and effluents indicating the common use of metamizole in Beijing. The similar concentrations of 1520$2520 \mathrm{ng} \mathrm{L}^{-1}$ and $1300-2240 \mathrm{ng} \mathrm{L}^{-1}$ for influents and effluents, respectively (Table 2), indicated limited elimination ( -22 to $27 \%$ ) of this substance by the WWTPs (Fig. 3). Concentrations reported for AAA in European WWTPs were much higher, ranging from 1100 to $15000 \mathrm{ng} \mathrm{L}^{-1}$ in influents and from 950 to $6000 \mathrm{ng} \mathrm{L}^{-1}$ in effluents (Zühlke, 2004; Kahle et al., 2009).

The anti-inflammatory drug diclofenac was present in Beijing's WWTPs at concentrations of $180-280 \mathrm{ng} \mathrm{L}^{-1}$ in the influents and similar concentrations of $140-300 \mathrm{ng} \mathrm{L}^{-1}$ in the effluents, again indicating little or negligible elimination ( $-7 \%$ to $25 \%$ ). Effluent concentrations in Beijing were lower than those reported for e.g. Switzerland (200-990 $\mathrm{n} \mathrm{L} \mathrm{L}^{-1}$, Tixier et al., 2003), whereas the limited elimination was similar to observations in Germany and Spain that spanned from $0 \%$ to $40 \%$ elimination in conventional activated sludge treatment (Joss et al., 2005; Radjenović et al., 2009).

\subsubsection{Antiepileptics}

The antiepileptic agent carbamazepine (CBMZ) and its metabolites, carbamazepine-10,11-dihydro-10,11-dihydroxy (CBMZDI) and carbamazepine epoxide, were analyzed in the wastewater samples. CBMZDI was the major metabolite present, ranging from 650 to $1020 \mathrm{ng} \mathrm{L}^{-1}$ in the influents, which was one order of magnitude higher than the concentration of its parent compound

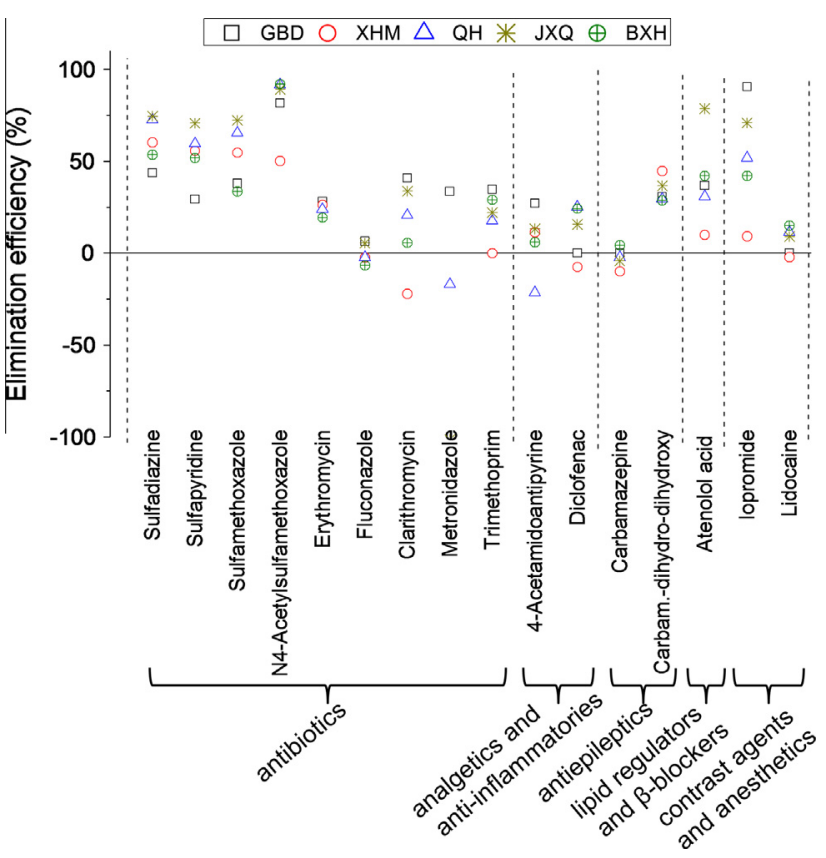

Fig. 3. Elimination efficiencies of Beijing's WWTPs for antibiotics, analgesics and anti-inflammatories, antiepileptics, lipid regulators and $\beta$-blockers, contrast agents and anesthetics.

carbamazepine (60-100 $\mathrm{ng} \mathrm{L}^{-1}$ ) (Table 2). Higher aqueous concentrations of CBMZDI were also reported in other studies (Miao and Metcalfe, 2003; Miao et al., 2005). This observation might be explained by the hydrophilicity of CBMZDI and that this compound is also being a metabolite of oxcarbazepine (Zhang et al., 2008). Carbamazepine epoxide concentrations were below the LOQ ( $3 \mathrm{ng} \mathrm{L}^{-1}$ ) in all samples. The elimination of both CBMZDI and carbamazepine was limited ( $-13 \%$ to $45 \%$ ) in the WWTPs, as found in other studies, due to the chemical inertness and weak adsorption of these compounds on sludge (Lin et al., 2009; Zhou et al., 2010; Sui et al., 2011; Bueno et al., 2012), as well as by the reformation from the conjugated forms by microbial activity during treatment (Miao et al., 2005).

\subsubsection{Contrast agents (iopromide)}

The concentrations of iopromide (IPM, contrast agent) in the influents (2.5-21.3 $\left.\mathrm{g} \mathrm{L}^{-1}\right)$ and effluents $\left(1.2-17.9 \mu \mathrm{g} \mathrm{L}^{-1}\right)$ were the highest among all pharmaceuticals detected. These levels were even higher than those reported in a compilation as a world average (0.03-7.5 and $0.25-9.3 \mu \mathrm{g} \mathrm{L}^{-1}$ in the in- and outflow, respectively, Miège et al., 2009). A range of $9-91 \%$ for the elimination efficiency of iopromide was observed in the five WWTPs (Fig. 3). Similar variations were also found in Swiss WWTPs, where no correlation between elimination efficiency and sludge age or treatment processes was found. The concentrations of iopromide also varied in the inflow of the five Beijing WWTPs, as they were higher in JXQ $\left(21.3 \mu \mathrm{g} \mathrm{L}^{-1}\right)$ and XHM $\left(19.7 \mu \mathrm{g} \mathrm{L}^{-1}\right)$ but clearly lower in $\mathrm{QH}$ (4.5 $\left.\mu \mathrm{g} \mathrm{L}^{-1}\right)$ and BXH $\left(2.5 \mu \mathrm{g} \mathrm{L}^{-1}\right)$ (Fig. S2). Joss et al. (2005) suggested that these high variations of the inflow concentrations were caused by irregular emission of the compound.

\subsubsection{Other pharmaceuticals}

Other pharmaceuticals, such as atenolol acid (metabolite of $\beta$-blocker metoprolol), ranged in concentration from 940 to $1380 \mathrm{ng} \mathrm{L}^{-1}$ in the influents. Considerable variation in efficiency of elimination was observed for atenolol acid (10-79\%) among the five WWTPs, probably because this compound may also be 
formed from atenolol during wastewater treatment (Radjenović et al., 2008). The anesthetic lidocaine was detected in all samples (137-180 $\mathrm{ng} \mathrm{L}^{-1}$ in influents, $120-180 \mathrm{ng} \mathrm{L}^{-1}$ in effluents), and was poorly eliminated (less than 15\%) in all five Beijing WWTPs.

\subsubsection{Elimination efficiency of pharmaceuticals by different WWTPS}

This study found high concentrations and low elimination efficiencies for several pollutants, including contrast agents, macrolides, some sulfonamides, metronidazole, and 4-acetamidoantipyrine in the Beijing WWTPs (Table 2, Fig. 3). Elimination of some pharmaceuticals, such as beta blockers and psycho-active drugs, during wastewater treatment could be predicted with a model using the transformation constants (Wick et al., 2009), but no general trend for the elimination of pharmaceuticals has been reported in the literature (Gulkowska et al., 2008; Zhou et al., 2010; Gao et al., 2012b; Verlicchi et al., 2012).

As mentioned in Section 3.2.1, Miège et al. (2009) assessed the elimination efficiencies of PPCPs in wastewater treatment around the globe and pointed out that activated sludge with nitrogen treatment (a low loaded activated sludge process) and membrane bioreactors showed the best efficiency. In our study, the WWTP with the oxidation ditch treatment (JXQ) was more efficient than $\mathrm{A} / \mathrm{A} / \mathrm{O}$ or $\mathrm{MBR}$ in removing sulfamethoxazole $+\mathrm{N} 4$-acetylsulfamethoxazole, atenolol acid, sulfadiazine, sulfapyridine and iopromide and showed elimination rates $>70 \%$ (Table 1 ). The sludge retention time (SRT) did not seem to be a decisive factor for the elimination efficiency of pharmaceuticals, since no trend in elimination efficiency was evident for the $\mathrm{QH}, \mathrm{GBD}$, and XHM treatment plants that used the same treatment technology (i.e., A/A/O treatment), despite their variations in SRT (Table 1). However, $\mathrm{QH}$ and XHM, with lower sludge retention times (13-15 d), showed a more efficient elimination of sulfadiazine and sulfapyridine when compared with GBD with a SRT of $20 \mathrm{~d}$, where the elimination of the sulfonamides was below 45\%. Finally, the membrane bioreactor (MBR) at BXH was no more efficient than the treatment processes used at the other WWTPs.

Sui et al. (2011) compared the elimination of pharmaceuticals over the course of one year in Beijing in two WWTPs that apply MBR and conventional activated sludge with biological nutrient elimination. They found a significantly better elimination of diclofenac and trimethoprim for the MBR (60\% in summer/autumn and $40 \%$ in winter/spring), while elimination was much lower or even negligible using the conventional treatment. The authors attributed the higher elimination of diclofenac and trimethoprim by MBR in summer/autumn to the higher biomass and longer sludge retention time 'which are often used to explain the variation of PPCPs elimination efficiency for WWTPs' (Miège et al., 2009).

\subsection{Occurrence of pesticides in WWTPS}

In general, concentrations of 20 pesticides and their transformation products analyzed in this study did not exceed $1000 \mathrm{ng} \mathrm{L}^{-1}$ in the five Beijing WWTPs (Table 2). Carbendazim (CBD) had highest concentrations in influents (360-580 $\mathrm{ng} \mathrm{L}^{-1}$ ) and effluents (370$610 \mathrm{ng} \mathrm{L}^{-1}$ ), which is in accordance with its widespread use as fungicide for the production of fruit and vegetables and in lawn maintenance in Beijing. The occurrence of different pesticides was quite similar in the studied WWTPs (Fig. 4a). Calculating the elimination of pesticides is not very meaningful because peak concentrations, commonly caused by disposal or application events, cause unreliable results with the time-proportional 24-h composite sampling scheme. Notably, however, no significant elimination was observed for any of the pesticides. In addition, March is at the early stage of the pesticides application period. Our sampling in this period may
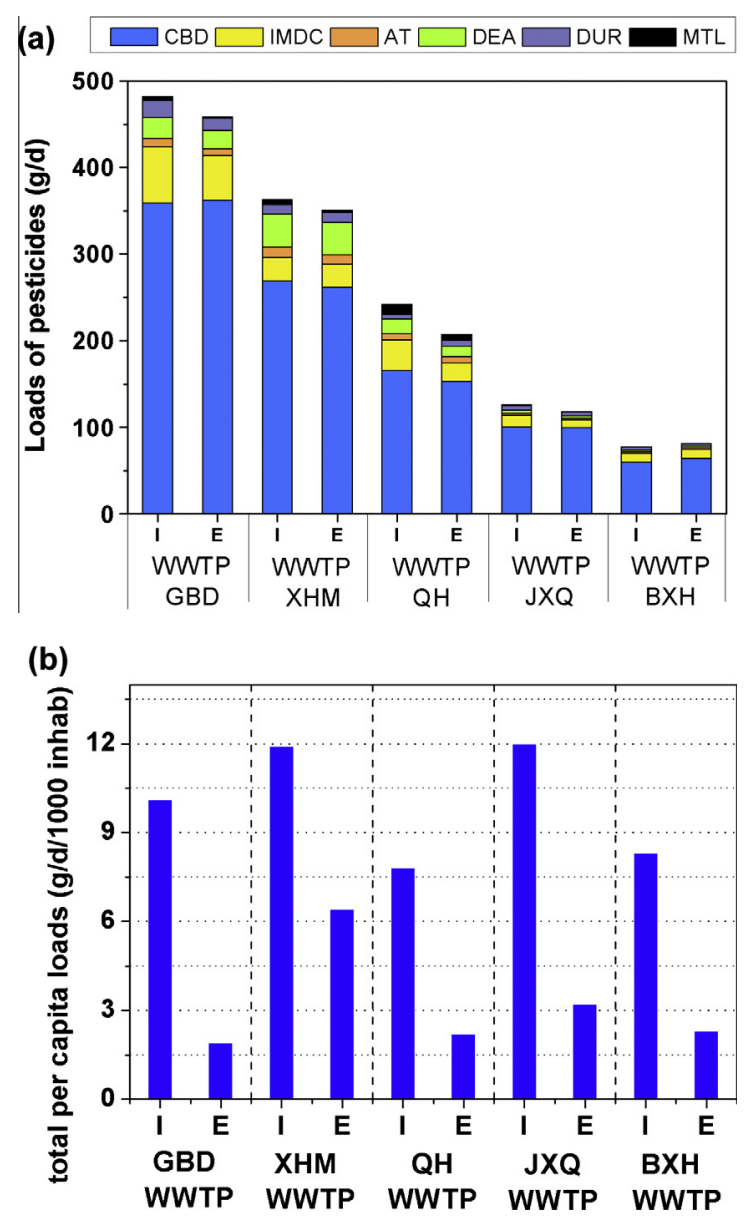

Fig. 4. (a) Cumulative loads ( $\mathrm{g} \mathrm{d}^{-1}$ of pesticides in Beijing WWTPs in March 2011. (CBD: Carbendazim; IMDC: Imidacloprid; AT: Atrazine; DEA: Atrazine-desethyl; DUR: Diuron; MTL: Metolachlor). (b) Total per capita loads of 27 detected polar micropollutants (including pharmaceuticals and household chemicals) in the influents (I) and effluents (E) of the Beijing WWTPs.

underestimate the concentrations and loads of pesticides in the wastewater systems.

\subsection{Pollutant loads in Beijing's WWTPs}

As can be seen in Table 3, the per capita loads of the pharmaceuticals bezafibrate, carbamazepine, diclofenac, mefenamic acid, and the household chemicals benzotriazole and methylbenzotriazole, were 6-100 times lower in influents in Beijing than in those reported for Switzerland and Italy (Castiglioni et al., 2006; Hollender et al., 2009). The opposite was the case for erythromycin (and $-\mathrm{H}_{2} \mathrm{O}$ ) and sulfadiazine, where per capita loads were higher in Beijing than in Switzerland and Italy (Table 3). Some Beijing WWTPs also exhibited higher loads of Iopromide and sulfamethoxazole.

The total loads of 27 pharmaceuticals and household chemicals ranged from 7.8-12.0 $\mathrm{g} \mathrm{d}^{-1} 1000$ inhabitants $^{-1}$ in the WWTP influents and were eliminated by $70-80 \%$ during the treatment processes, except at the XHM WWTP (46\%) (Fig. 4b). The lower total elimination at the XHM WWTP was mainly due to the low elimination efficiency for iopromide, which is among the most abundant and persistent contaminants (Fig. 3). Pesticides loads discharged by the individual WWTPs to the rivers were $80-460 \mathrm{~g} \mathrm{~d}^{-1}$ (Fig. 4a). Per capita loads of the pharmaceuticals and household chemicals discharged from each WWTP to the Haihe river system were 1.9-6.4 $\mathrm{g} \mathrm{d}^{-1} 1000$ inhabitants $^{-1}$ (Fig. 4b). Therefore, about 
Table 3

Per capita loads of selected micropollutants in the influent of Beijing WWTPs compared to values from Switzerland (Hollender et al., 2009) and Italy (Castiglioni et al., 2006).

\begin{tabular}{llll}
\hline & \multicolumn{2}{l}{ Per capita loads $\left(\mathrm{g} \mathrm{d}^{-1} 1000\right.$ inhab $\left.^{-1}\right)$} \\
\cline { 2 - 4 } & $\begin{array}{l}\text { Beijing } \\
(5 \text { WWTPs })\end{array}$ & $\begin{array}{l}\text { Switzerland } \\
(1 \text { WWTP })\end{array}$ & $\begin{array}{l}\text { Italy } \\
(6 \text { WWTPs })\end{array}$ \\
\hline $\begin{array}{llll}\text { Household chemicals } \\
\text { Benzotriazole }\end{array}$ & $0.11-0.27$ & 1.94 & \\
Methylbenzotriazole & $0.06-0.13$ & 0.39 & \\
Pharmaceuticals & & & nd-0.21 \\
Iopromide & $0.52-4.24$ & 1.04 & \\
SMX + N4-AcSMX & $0.10-0.99$ & 0.20 & nd-0.001 \\
Diclofenac & $0.04-0.05$ & 0.32 & nd-0.39 \\
Mefenamic acid & $0.002-0.006$ & 0.55 & nd-0.05 \\
Erythromycin & $0.07-0.08$ & 0.01 & $0.02-0.68$ \\
Sulfadiazine & $0.04-0.06$ & 0.03 & \\
Carbamazepine & $0.01-0.02$ & 0.11 & \\
Clarithromycin & $0.03-0.05$ & 0.09 & 0.09 \\
Bezafibrate & $0.01-0.03$ & & \\
\hline
\end{tabular}

$96 \mathrm{~kg}$ of polar micropollutants reach the surface waters this way every day from the five WWTPs in Beijing.

\section{Conclusions}

Effluents from WWTPs are the main water source for rivers in the Beijing region and other cities located in the water-scarce region of Northern China (Pernet-Coudrier et al., 2012). Therefore, the polar micropollutants investigated in this study, as well as thousands of other organic chemicals that can be present today in wastewater effluents, significantly contribute to the organic pollutant loads in the receiving surface waters. Improvement and monitoring of the quality of WWTP effluents is even more pressing because precious water is pumped for irrigation and other uses in the agricultural areas downstream of Beijing. Consequently, accumulation of persistent chemicals in soils jeopardizing food quality and bearing health risks of the population are pressing problems demanding highest priority for political action (Liu, 2010). Additionally, the potential risks to ecosystems due to sewage irrigation extend to spreading antibiotic-resistance genes, which are currently discussed as emerging environmental contaminants (Czekalski et al., 2014). Studies on elimination of pharmaceuticals during wastewater treatment suggest that activated carbon and ozonation are the most promising processes for improving the efficiency of pollutant removal by WWTPs (Larsen et al., 2004; Hollender et al., 2009).

This study serves as a baseline and point of reference for further assessing per-capita loads and the ecological impact of wastewater-borne pollutants. The consumption of pharmaceuticals and household chemicals are expected to increase with the rapid development of China. This will lead to higher pollutant concentrations in wastewater, and, without more efficient wastewater treatment, cause higher loads to irrigated cropland and the aquatic environment.

\section{Acknowledgements}

We thank Philippe Longrée and Florian Heeb for screening of the initial samples, and Falk Dorusch and Alfred Lück for laboratory assistance. This work was supported by the Sino-Swiss Science and Technology Cooperation Program of the Swiss State Secretariat for Education and Research, Project No. IZL CZ2 123912, and the External Cooperation Program of the Chinese Academy of Sciences, Grant GJHZ0908.

\section{Appendix A. Supplementary material}

Supplementary data associated with this article can be found, in the online version, at http://dx.doi.org/10.1016/j.chemosphere. 2014.09.027.

\section{References}

Bueno, M.J.M., Gomez, M.J., Herrera, S., Hernando, M.D., Agüera, A., Fernández-Alba A.R., 2012. Occurrence and persistence of organic emerging contaminants and priority pollutants in five sewage treatment plants of Spain: two years pilot survey monitoring. Environ. Pollut. 164 (5), 267-273.

Buerge, J.I., Poiger, T., Müller, D.M., Buser, H.R., 2003. Caffeine, an anthropogenic marker for wastewater contamination of surface waters. Environ. Sci. Technol. 37 (4), 691-700.

Buerge, J.I., Poiger, T., Müller, D.M., Buser, H.R., 2006. Combined sewer overflows to surface waters detected by the anthropogenic marker caffeine. Environ. Sci. Technol. 40 (13), 4096-4102.

Castiglioni, S., Bagnati, R., Fanelli, R., Pomati, F., Calamari, D., Zuccato, E., 2006. Removal of pharmaceuticals in sewage treatment plants in Italy. Environ. Sci. Technol. 40 (1), 357-363.

Czekalski, N., Díez, G.E., Bürgmann, H., 2014. Wastewater as a point source of antibiotic-resistance genes in the sediment of a freshwater lake. ISME J. 8, 1381-1390.

Gao, L.H., Shi, Y.L., Li, W.H., Liu, J.M., Cai, Y.Q., 2012a. Occurrence, distribution and bioaccumulation of antibiotics in the Haihe River in China. J. Environ. Monitor. 14 (4), 1248-1255.

Gao, L.H., Shi, Y.L., Li, W.H., Niu, H.Y., Liu, J.M., Cai, Y.Q., 2012b. Occurrence of antibiotics in eight sewage treatment plants in Beijing, China. Chemosphere 86 (6), 665-671.

García-Glaán, J.M., Díaz-Cruz, S.M., Barceló, D., 2008. Identification and determination of metabolites and degradation products of sulfonamide antibiotics. Trends Anal. Chem. 27 (11), 1008-1022.

Gulkowska, A., Leung, H.W., So, M.K., Taniyasu, S., Yamashita, N., Yeung, W.Y.L. Richardson, J.B., Lei, A.P., Giesy, J.P., Lam, K.S.P., 2008. Removal of antibiotics from wastewater by sewage treatment facilities in Hong Kong and Shenzhen, China. Water Res. 42 (1-2), 395-403.

Heeb, F., Singer, H., Pernet-Coudrier, B., Qi, W.X., Liu, H.J., Longrée, P., Müller, B. Berg, M., 2012. Organic micropollutants in rivers downstream of the megacity Beijing: sources and mass fluxes in a large-scale wastewater irrigation system. Environ. Sci. Technol. 46 (16), 8680-8688.

Hollender, J., Zimmermann, G.S., Koepke, S., Krauss, M., Mcardell, S.C., Ort, C., Singer, H., Gunten, V.U., Siegrist, H., 2009. Elimination of organic micropollutants in a municipal wastewater treatment plant upgraded with a full-scale postozonation followed by sand filtration. Environ. Sci. Technol. 43 (20), 7862-7869.

Joss, A., Keller, E., Alder, A.C., Göbel, A., McArdell, C.S., Ternes, T., Siegrist, H., 2005 Removal of pharmaceuticals and fragrances in biological wastewater treatment Water Res. 39 (18), 3139-3152.

Kahle, M., Buerge, J.I., Müller, D.M., Poiger, T., 2009. Hydrophilic anthropogenic markers for quantification of wastewater contamination in ground- and surface waters. Environ. Toxicol. Chem. 28 (12), 2528-2536.

Kovalova, L., Siegrist, H., Singer, H., Wittmer, A., McArdell, S.C., 2012. Hospital wastewater treatment by membrane bioreactor: performance and efficiency for organic micropollutant elimination. Environ. Sci. Technol. 46, 1536-1545.

Larsen, A.T., Lienert, J., Joss, A., Siegrist, H., 2004. How to avoid pharmaceuticals in the aquatic environment. J. Biotechnol. 113 (1-3), 295-304.

Li, W.H., Shi, Y.L., Gao, L.H., Liu, J.M., Cai, Y.Q., 2013. Occurrence and removal of antibiotics in a municipal wastewater reclamation plant in Beijing, China. Chemosphere 92 (4), 435-444.

Lin, A., Yu, C., Yu, T.H., Lateef, K.S., 2009. Removal of pharmaceuticals in secondary wastewater treatment processes in Taiwan. J. Hazard. Mater. 167 (8), 11631169.

Liu, L., 2010. Made in China: cancer villages. Environ.: Sci. Policy Sustain. Dev. 52 (2), 8-21.

Luo, Y., Xu, L., Rysz, M., Wang, Y., Zhang, H., Alvarez, J.J.P., 2011. Occurrence and transport of tetracycline, sulfonamide, quinolone, and macrolide antibiotics in the Haihe River Basin, China, Environ. Sci. Technol. 45 (2), 1827-1833.

Mead, R.N., Morgan, J.B., Avery, J.B., Kieber, J.R., Kirk, M.A., Skrabal, A.S., Willey, D.J., 2009. Occurrence of the artificial sweetener sucralose in coastal and marine waters of the United States. Mar. Chem. 116, 13-17.

Miao, X.S., Metcalfe, C.D., 2003. Determination of carbamazepine and its metabolites in aqueous samples using liquid chromatography-electrospray tandem mass spectrometry. Anal. Chem. 75 (15), 3731-3738.

Miao, X.S., Yang, J.J., Metcalfe, C.D., 2005. Carbamazepine and its metabolites in wastewater and in biosolids in a municipal wastewater treatment plant Environ. Sci. Technol. 39 (19), 7469-7475.

Miège, C., Choubert, M.J., Ribeiro, L, Eusèbe, M., Coquery, M., 2009. Fate of pharmaceuticals and personal care products in wastewater treatment plants conception of a database and first results. Environ. Pollut. 157, 1721-1726.

Ort, C., Lawrence, G.M., Rieckermann, J., Joss, A., 2010a. Sampling for pharmaceuticals and personal care products (PPCPs) and illicit drugs in wastewater systems: are your conclusions valid? A critical review. Environ. Sci. Technol. 4 (16), 6024-6035. 
Ort, C., Lawrence, G.M., Reungoat, J., Mueller, F.J., 2010b. Sampling for PPCPs in wastewater systems: comparison of different sampling modes and optimization strategies. Environ. Sci. Technol. 44 (16), 6289-6296.

Pernet-Coudrier, B., Qi, W.X., Liu, H.J., Müller, B., Berg, M., 2012. Sources and pathways of nutrients in the semi-arid region of Beijing-Tianjin, China. Environ. Sci. Technol. 46, 5294-5301.

Radjenović, J., Pérez, S., Petrović, M., Barceló, D., 2008. Identification and structural characterization of biodegradation products of atenolol and glibenclamide by liquid chromatography coupled to hybrid quadrupole time-of-flight and quadrupole ion trap mass spectrometry. J. Chromatogr., A 1210 (11), 142-153.

Radjenović, J., Petrović, M., Barceló, D., 2009. Fate and distribution of pharmaceuticals in wastewater and sewage sludge of the conventiona activated sludge (CAS) and advanced membrane bioreactor (MBR) treatment. Water Res. 43 (3), 831-841.

Reemtsmaa, T., Miehe, U., Duennbier, U., Jekel, M., 2010. Polar pollutants in municipal wastewater and the water cycle: Occurrence and removal of benzotriazoles. Water Res. 44 (1), 596-604.

Standley, J.L., Kaplan, A.L., Smith, D., 2000. Molecular tracers of organic matter sources to surface water resources. Environ. Sci. Technol. 34 (15) 3124-3130.

Stoob, K., Singer, P.H., Goetz, W.C., Ruff, M., Mueller, R.S., 2005. Fully automated online solid phase extraction coupled directly to liquid chromatographytandem mass spectrometry Quantification of sulfonamide antibiotics, neutral and acidic pesticides at low concentrations in surface waters. J. Chromatogr., A 1097 (9), 138-147.

Sui, Q., Huang, J., Deng, S.B., Yu, G., Fan, Q., 2010. Occurrence and removal of pharmaceuticals, caffeine and DEET in wastewater treatment plants of Beijing, China. Water Res. 44 (2), 417-426.

Sui, Q., Huang, J., Deng, S.B., Chen, W.W., Yu, G., 2011. Seasonal variation in the occurrence and removal of pharmaceuticals and personal care products in different biological wastewater treatment processes. Environ. Sci. Technol. 45 (3), 3341-3348.

Tixier, C., Singer, P.H., Oellers, S., Müller, R.S., 2003. Occurrence and fate of carbamazepine, clofibric acid, diclofenac, ibuprofen, ketoprofen, and naproxen in surface waters. Environ. Sci. Technol. 37 (6), 1061-1068.

Tollefsen, E.K., Nizzetto, L., Huggett, B.D., 2012. Presence, fate and effects of the intense sweetener sucralose in the aquatic environment. Sci. Total Environ. 438 (9), 510-516.

Verlicchi, P., Aukidy, A.M., Zambello, E., 2012. Occurrence of pharmaceutical compounds in urban wastewater: removal, mass load and environmental risk after a secondary treatment-a review. Sci. Total Environ. 429 (5), 123-155.

Wick, A., Fink, G. Joss, A., Siegrist, H., Ternes, A.T, 2009. Fate of beta blockers and psycho-active drugs in conventional wastewater treatment. Water Res. 43 1060-1074.

Zhang, Y.J., Geißen, S.U., Gal, C., 2008. Carbamazepine and diclofenac: removal in wastewater treatment plants and occurrence in water bodies. Chemosphere 73 (8), 1151-1161.

Zhou, H.D., Wu, C.Y., Huang, X., Gao, M.J., Wen, X.H., Tsuno, H., Tanaka, H., 2010. Occurrence of selected pharmaceuticals and caffeine in sewage treatment plants and receiving rivers in Beijing, China. Water Environ. Res. 82 (11), 22392248 .

Zhou, L.J., Ying, G.G., Liu, S., Zhao, J.L., Yang, B., Chen, Z.F., Lai, H.J., 2013. Occurrence and fate of eleven classes of antibiotics in two typical wastewater treatment plants in South China. Sci. Total Environ. 452-453 (3), 365-376.

Zühlke, S., 2004. Verhalten von Phenazonderivaten, Carbamazepin und estrogenen Steroiden während verschiedener Verfahren der Wasseraufbereitung. PhD thesis. Technische Universität, Berlin, Germany. 